\title{
Sınıf Öğretmeni Adaylarının Müziksel Bilgilerinin, Blokflüt Çalma ve Müziksel Okuma Düzeyleri ile Karşılaştırılması
}

DOI: $10.26466 /$ opus.653521

$*$

\author{
Aylin Mentiş Köksoy ${ }^{*}$ Şenol Afacan ${ }^{* *}$ \\ ${ }^{*}$ Doç. Dr., Ege Üniversitesi, Eğitim Fakültesi, İzmir/Türkiye \\ E-Posta: aylinmentiskoksoy@gmail.com ORCID: 0000-0003-4549-0579 \\ ** Dr. Öğr. Üyesi, Kırşehir Ahi Evran Üniversitesi, Neşet Ertaş Güzel Sanatlar Fak, Kırşehir/Türkiye \\ E-Posta: senolafacan@gmail.com \\ ORCID: $\underline{0000-0001-7564-1695}$
}

Öz

Sını öğretmeni adaylarının müzik derslerinde gereken donanıma sahip olmaları, nitelikli müzik dersleri işlemeleri ile doğrudan ilgilidir. Bu çalışmada Ege Üniversitesi Eğitim Fakültesi Sınıf Eğitimi Anabilim dalında öğenim gören sınıf öğretmeni adaylarının müzik dersi temel bilgilerini ve müzik eğitimi derslerinde sınıf ortamında çalışılan eğitsel müzik dağarcığına ilişkin örneklerde blokflüt çalma ve müziksel okuma beceri düzeylerinin belirlenerek karşılaştırılması amaçlanmıştır. Araştırmada eğitsel müzik dağarındaki şarkılarda geçen müziksel bilgilere yönelik sınıf öğretmeni adaylarının bilgi düzeylerini ölçmek için Afacan (2010) tarafindan geliştirilen 37 maddeden oluşan başarı testi kullanılmıştır. Geliştirilen başarı testinin KR-20 güvenirlik katsayısı 0.81'dir. Çalışma müzik eğitimi dersi almış 3.sınıfta öğrenim gören 50 sinı öğretmeni adayı ile yapılmıştır. Başarı testinden en yüksek ve en düşük puan alan toplam 28 öğretmen adayının müzik dersinde çalıştıkları şarkılarda blokflüt çalma ve müziksel okuma beceri düzeyleri araştırmacılar tarafından hazırlanan dereceli puanlama anahtarı kullanılarak değerlendirilmiştir. Araştırma sonucunda sını f̈ğretmeni adaylarının Öğretmen adaylarının okul şarkılarında geçen temel müzik bilgilerini ölçen başarı testine göre yetersiz oldukları, çalışma kapsamında belirlenen okul şarkılarında blokflüt çalma ve müziksel okuma düzeylerinin orta ve zayıf düzeyde olduğu saptanmiştır.

Anahtar Kelimeler: Sını öğretmeni adayı, Müziksel bilgi, Blokflüt çalma, Müziksel okuma Dereceli puanlama anahtar 


\title{
Comparison of Musical Knowledge of Pre-Service Teachers with Block flute Playing and Musical Reading Levels
}

\begin{abstract}
It is directly related to the fact that the prospective classroom teachers have the necessary equipment in music lessons. In this study, it is aimed to compare the basic knowledge of music teacher and music reading skill levels of class teacher candidates studying at Ege University Faculty of Education Class Education Department by identifying block flute playing and musical reading skill levels. In the study, 37-item achievement test developed by Afacan (2010) was used to measure the level of knowledge of prospective classroom teachers for musical information in songs in educational music repertoire. The $K R-20$ reliability coefficient of the developed achievement test was 0.81 . The study was carried out with 50 prospective classroom teachers who took music education course. A total of 28 prospective teachers with the highest and lowest scores in the achievement test were evaluated using the graded scoring key prepared by the researchers. As a result of the research, it was determined that prospective classroom teachers were inadequate according to the achievement test which measured basic music knowledge of school songs and it was found that block flute playing and musical reading levels were moderate and weak.
\end{abstract}

Keywords: Primary school teacher candidate, Musical knowledge, Block Flute playing, Musical reading Grade scoring key 


\section{Giriş}

Sınıf öğretmenleri, çocukların zihni ve çalışma alışkanlıklarını geliştirmede, ilkokul birinci sınıftan beşinci sınıfa kadar eğitim vermekle yükümlü ve onların eğitim hayatını şekillendirmede de önemli bir rol oynayan kişilerdir. Ayrıca çocukların kendilerini ifade etmelerinde, ilkokul ve sonrasında gelişmeleri için ihtiyaç duyacakları bilgi, beceri ve nitelikleri edinmelerini sağlayan kişilerdir. Sınıf öğretmenleri 4 yıllık lisans eğitimleri boyunca öğrencilere temel olabilecek çeşitli derslerin yanında müzik gibi çocukların sosyalleşmesini sağlayan, beyin gelişimini olumlu yönde etkilediği birçok araştırmalarla kanıtlanan ve çocukların ruhsal gelişimlerini de olumlu yönde desteklediği bilinen derslerin başında müzik gelir.

Müzik bir sanat, bilim ve dildir. Bu dili, çocukluktan itibaren öğrenmeye başlayanlar ileri yaşlarda öğrenmeye başlayanlardan daha çabuk öğrenir ve başarılı olurlar. Özellikle de ilköğretim yıllarında verilen genele müzik eğitimi, müzik eğitimin temelini oluşturur. İlköğretimdeki müzik eğitiminin yeterli olmaması halinde çocuğun müzik eğitimi açısından gelişmeye en uygun en verimli çağları kaybedilecek ve ilköğretimden sonraki okul yıllarında verilecek olan müzik eğitiminde ise istenilen başarı düzeyinin yakalanması güçleşecektir (Milli, 1997, s.7).

Sını öğretmeni adaylarından alana özgü geliştirilen yeterlik ve becerileri kazanmaları da beklenmektedir. Milli Eğitim Bakanlığı Öğretmen Yetiştirme ve Eğitimi Genel Müdürlüğü tarafından belirlenen ve 2008 yılında yürürlüğe giren Sınıf öğretmenlerinin sahip olması gereken özel alan yeterliklerinden biri "sanat ve estetik" tir. Bu yeterlik alanı; öğrencilerin güzel sanatlarla (müzik, resim) ilgili temel bilgilere sahip olmayı, sanatsal etkinlikleri öğrenme sürecinde kullanabilme uygulamalarını kapsamaktadır (MEB, 2008, s.10). İlköğretim müzik eğitimi, müziksel işitme, müziksel söyleme, çalgı çalma, müzik dinleme, müziksel duyarlılığı arttırma, müzik zevki geliştirme ve müziksel kişilik geliştirme gibi temel boyutları içermektedir (Kocabaş, 1995, s.5).

Nitelikli bir sınıf öğretmeni; genel kültür derslerinin yanı sıra özel alan derslerinde de donanımlı olmalıdır. Örneğin ilkokul müzik dersi öğretim programında yer alan temel müzik yazı ve öğelerini bilmeli, şarkıları doğru şekilde seslendirebilmeli, bir okul çalgısı veya orff çalgısı ile şarkılara eşlik edebilmeli, değişik türde kültürlerin müziklerinden örnekleri öğrencilere sunabilmeli ve öğrencilerin müziksel yaratıcılık yönlerini ortaya çıkartmalarını 
sağlamalıdır. İlköğretim çağı çocuğunun eğitim sürecinde kendisini kuşatan ses ağı ve bu ağın örüldüğ̈̈ ses çevresi içinde müzik ve müziksel çevresi doğal, toplumsal ve kültürel seslerden bambaşka özellikler taşır (Uçan, 1999, s.2).

İlkokullarda gerçekleştirilen müzik öğretimi, eğitsel müzik öğretimi kapsamında gerçekleştirilmektedir. Her ilkokul çocuğunun etkili bir eğitim temeli-boyutu-aracı-yöntemi-alanı olan bu öğrenimi gördüğü düşünüldüğünde, bu kurumlarda gerçekleştirilen müzik öğretiminin tamamlayıcı, destekleyici, yaratıcılı̆̆a ve ileriye götüren işlevleri ile göz ardı edilmeden ele alınması gerekmektedir (Sun, 1969; Yıldız, 2006; aktaran Yazıc1, 2016 ).

Öğretmen, ancak doğru ve tutarlı bir müzik yeteneği ya da müzikalite anlayışına sahipse müziği doğru anlama, yapma, yaratma, kullanma eğitimi verebilir; öğrencinin müziksel yeteneklerini doğru ve tutarlı biçimlendirebilir, geliştirebilir (Uçan, 2005).

Sınıf öğretmeni adaylarının, müziksel bilgi ve becerileri kazanmaları, öğrendikleri teorik bilgileri uygulayabilme becerileri kazanmaları ve bu konularda nitelikli olarak yetiştirilmeleri önem taşımaktadır (Çevik, 2011; s.147). Sını öğretmeni adayları eğitimleri süresince müzik öğretiminin boyutları olan ses eğitimi, kulak eğitimi, çalg1 eğitimi, müziksel bilgi eğitimi, müziksel beğeni eğitimini gerçekleştirebilecek yeterlilikte olmalıdır (Afacan, 2007, s.89).

Sınıf öğretmeni adaylarının, müzik derslerinde deşifre yapabilme, çocuk şarkılarını çalma ve söyleme becerilerinin geliştirilmesi oldukça önemlidir. Şarkıları doğru çalmaları ve doğru söylemeleri istenir zira şarkı söylemek eskiden beri süregelen bir müzik etkinliğidir. Çalma ve söylemenin yanı sıra, temel müzik bilgi düzeylerine de hâkim olmaları beklenir. Öğretmen adaylarının gerekli müziksel donanıma sahip olmaları, onların ileriki yaşamlarında kendilerine daha özgüvenli, etkin ve üretken olmalarını sağlayacaktır. Müzik derslerinde şarkı öğretimi, blokflüt çalma ve müziksel okumanın yanında öğrencilerin müzikten zevk almaların sağlayarak, onları daha çok motive edecek ve bireysel gelişimlerine olumlu yönde fayda sağlayacaktır. Müzik öğretimi, öğrencilerin temel müzik bilgi düzeyleri, çalma ve müziksel okuma süreçlerini kapsayan çok yönlü bir süreçtir.

Sınıf öğretmenliği lisans programında "Müzik" ve "Müzik Öğretimi" dersleriyle öğrenciler ikinci sınıfın birinci yarıyılı ve ikinci sınıfın ikinci yarı- 
yılında bu dersleri almaktadırlar. Bu derslerin içeriği; “Müziğin temel bileşenleri, temel müzik bilgileri; nota bilgisi, müzikte aralık kavramı, müzikte ritim kavramı, şarkı dağarcığı oluşturulması; Türkiye'de ve dünyada müzik tür ve biçimleri; geleneksel müzikten çağdaş müziğe geçiş, çalg1 öğretimi, toplu çalma ve söyleme, eğitimde müziğin rolü, yaratıcıllğı geliştirmede müziksel işitme. Müzik öğretim yöntem ve teknikleri, nota öğretimi teknikleri, ritim ve melodiden yararlanarak orff çalgılarıyla çocuklar için şarkıların düzenlenmesi, çalgının şarkı öğretiminde etkili kullanımı, oyun, müzik, dans, drama ve konuşma ilişkisi, müzik-estetik ilişkisi ile müziksel beğeninin geliştirilmesi, müzik dersi etkinliklerinin diğer disiplinlerle ilişkilendirilmesi, İlköğretim müzik programı ile ilgili etkinlik uygulamaları. şeklinde tanımlanmaktadır (Yüksek Öğretim Kurulu [YÖK])

İlköğretim müzik ve müzik öğretimi ile ilgili alan yazında; Nacakcl, 2006; Şaktanl, 2004; Küçüköncü, 2000; Otacıŏlu, 2007; Topoğlu, 2015; Dinç, AltunGül, Uzuner, 2018; Kocabaş, 2000; Barış ve Özata, 2009; Göğüş, 2008; Kocabaş ve Selçioğlu, 2006; Şahin ve Toraman, 2004; Umuzdaş ve Işıldak; 2019; Ustaoğlu ve Barış, 2017; Yazıc1, 2012; Şahin ve Aksüt, 2002; Kutluk, 2010; Yünlü ve Sağlam, 2004; Öztürk ve Öztürk, 2007; Arapgirlioğlu ve Karagöz, 2010; Yazıc1, 2016; Demirbatır ve Helvac1, 2006; Koca ve Kurtaslan, 2013; Nart, 2014; K1lıç, 2011; Afacan, 2010; Yılmaz ve Orhan, 2018; bu çalışmalar mevcuttur.

$\mathrm{Bu}$ araştırmalar çoğunlukla sınıf öğretmenlerine ve sınıf öğretmeni adaylarına yönelik yapılmıştır. Bu araştırma da sınıf öğretmeni adayları ile birlikte yapılmış olup, sınıf öğretmeni adaylarının temel müzik bilgi düzeylerinin, blok flüt çalma ve müziksel okuma becerileri ile karşılaştırılması incelenmeye çalışılmıştır. Böylece sınıf öğretmeni adaylarının bu konularda yeterlikleri ya da yetersizlikleri saptanmaya çalışılarak literatüre katkı sağlayacağı düşünülmektedir.

Buna göre araştırmanın problem cümlesi Sınıf Öğretmeni adaylarının lisans eğitiminde aldıkları müzik ve müzik öğretimi dersleri sonucunda temel müzik bilgi düzeyleri ile blokflüt çalma ve müziksel okuma becerileri nasıldir?

\section{Alt Problemler}

1. Sını öğretmeni adaylarının, temel müzik bilgilerini içeren başarı testinde yer alan sorulara verdikleri doğru cevapların dağılımı nasıldır? 
2. Sınıf öğretmeni adaylarının müzik eğitimi derslerinde, öğretimi yapılan şarkılarda blokflüt çalma düzeyleri nedir?

3. Sınıf öğretmeni adaylarının müziksel okuma (solfej) düzeyleri nedir?

\section{Amaç}

Bu çalışmada sınıf öğretmeni adaylarının temel müzik bilgi düzeyleri, blokflüt çalma ve müziksel okuma beceri düzeylerinin belirlenmesi amaçlanmıştır.

\section{Önem}

İlköğretim müzik dersleri müzik eğitiminin temelini oluşturmakla beraber, çocukların yeteneğini geliştirip, onları yönlendirme de önemli bir adımdır. Bilişsel, duyuşsal, sosyal ve psikomotor özelliklerinin bir bütün olarak ele alınması gereken bir süreçtir (Arapgirlioğlu, Karagöz, 2010; S, 184). Buradan da anlaşılacağı üzere müziğin, çocukların gelişimi üzerinde etkisi oldukça büyüktür. Bu nedenle müzik dersinin ilkokullarda daha etkili verilebilmesi için bu dersleri verecek olan sınıf öğretmenin yetkinliği ve niteliği önemlidir. Bu kapsamda, bu çalışma örgün eğitimde sınıf öğretmeni adaylarının, temel müzik bilgi düzeyleri, blokflüt çalma ve müziksel okuma beceri düzeylerinin belirlenmesi açısından önem arz etmektedir. Çalışmanın verilerinden yola çıkılarak lisans düzeyinde müzik eğitimi alan sınıf öğretmeni adaylarının durumları belirlenerek, alınması gereken önlemler hakkında, bu çalışmanın yol göstereceği düşünülmektedir.

\section{Yöntem}

\section{Araştırma Modeli}

Çalışmada karma yöntemli desenler içerisinde yer alan yakınsayan paralel karma desen kullanılmıştır. Bu desende araştırmacı genellikle nitel ve nicel veri türünü yaklaşık olarak aynı zaman diliminde toplar ve sonrasında bu bilgileri genel sonuçları verirken bütünleştirerek yorumlar. Birbiriyle uyuşmayan bulgular ayrıntılı bir biçimde incelenir (Creswell, 2017). 


\section{Araştırma Grubu}

Araştırma grubunu 2019-2020 eğitim ve öğretim yılında Ege Üniversitesi Eğitim Fakültesi Sınıf Eğitimi Anabilim dalında öğrenim gören müzik eğitimi dersi almış 3. sınıf toplam 50 öğretmeni adayı oluşturmaktadır.

Tablo. 1 Araştırma grubu demografik özellikleri

\begin{tabular}{lll}
\hline Cinsiyet & f & \% \\
\hline Kadın & 38 & 76 \\
\hline Erkek & 12 & 24 \\
\hline Toplam & 50 & 100 \\
\hline
\end{tabular}

\section{Veri Toplama Araçlarn}

Verilerin toplanması amacıyla çalışmanın ilk bölümünde Afacan (2010) tarafından geliştirilen sınıf öğretmeni adaylarının çocuk şarkılarını bilişsel çözümlemeye yönelik başarı testi kullanılmıştır. Toplam 37 sorudan oluşan başarı testinin KR-20 güvenirlik katsayısı 0.81 'dir. Çalışmanın ikinci bölümünde başarı testine verilen cevaplara göre belirlenen alt ve üst grupta yer alan toplam 28 öğretmen adayı ile müzik eğitimi derslerinde sınıf ortamında çalışılan ve çalışma kapsamında belirlenen okul şarkılarında bireysel blokflüt çalma ve müziksel okuma becerileri araştırmacılar tarafından dereceli puanlama anahtarı kullanılarak değerlendirilmiştir.

Uygulamada kullanılmak üzere hazırlanan dereceli puanlama anahtarları iki alan uzmanı tarafından puanlandırılmıştır. Verilen puanlar karşılaştıııld1ğında görüş birliği ve görüş ayrilığı tespit edilerek dereceli puanlama anahtarlarının güvenirliği Miles ve Huberman'ın (1994) Güvenirlik= Görüş birliği/Görüş birliği+Görüş ayrılığı formülü kullanılarak hesaplanmıştır. Bu araştırmaya özgü olarak gerçekleştirilen güvenirlik çalışmasında uzmanlar arasında \%90 oranında bir uzlaşma (güvenirlik) sağlanmıştır. Miles ve Huberman (1994) araştırmacı değerlendirmeleri arasındaki uyumun \%90 ve üzeri olması gerektiğini belirtmiştir. 


\begin{tabular}{|c|c|c|c|c|}
\hline Gözlenen & Çok iyi & İyi & Orta & Zayif \\
\hline Davranıșlar & 4 & 3 & 2 & 1 \\
\hline $\begin{array}{l}\text { Notaları doğru } \\
\text { ve temiz } \\
\text { seslerle çalma }\end{array}$ & $\begin{array}{l}\text { Tüm notalar } \\
\text { doğru ve temiz } \\
\text { seslerle } \\
\text { çalınmıştır. }\end{array}$ & $\begin{array}{l}\text { Notalar genel } \\
\text { olarak doğru ve } \\
\text { temiz } \\
\text { çalınmıştır }\end{array}$ & $\begin{array}{l}\text { Notaların doğru } \\
\text { ve temiz } \\
\text { çalınmasında } \\
\text { bazen hatalar } \\
\text { yapmıștır. }\end{array}$ & $\begin{array}{l}\text { Notalar doğru ve } \\
\text { temiz } \\
\text { çalınmamıştır. }\end{array}$ \\
\hline $\begin{array}{l}\text { Notaları süre } \\
\text { değerlerine } \\
\text { uygun olarak } \\
\text { çalma }\end{array}$ & $\begin{array}{lr}\text { Şarkıda geçen } \\
\text { notalar } & \text { süre } \\
\text { değerlerine göre } \\
\text { çalınmıştır. }\end{array}$ & $\begin{array}{lr}\text { Şarkıda } & \text { geçen } \\
\text { notalar süre } \\
\text { değerlerine göre } \\
\text { genel olarak } \\
\text { doğru } \\
\text { çalınmıștır. }\end{array}$ & $\begin{array}{l}\text { Şarkıda geçen } \\
\text { notalar süre } \\
\text { değerlerine göre } \\
\text { çalınmasında } \\
\text { bazen hatalar } \\
\text { yapılmıștır. }\end{array}$ & $\begin{array}{l}\text { Şarkıda geçen } \\
\text { notalar süre } \\
\text { değerlerine } \\
\text { uygun } \\
\text { çalınmamıştır. }\end{array}$ \\
\hline Bütünlük & $\begin{array}{l}\text { Şarkı baştan } \\
\text { sona } \\
\text { duraksamadan } \\
\text { çalınmıştır. }\end{array}$ & $\begin{array}{l}\text { Şarki baştan } \\
\text { sona genel } \\
\text { olarak } \\
\text { duraksamadan } \\
\text { çalınmıștır. }\end{array}$ & $\begin{array}{l}\text { Şarkı baştan } \\
\text { sona ara sıra } \\
\text { duraksamalar } \\
\text { yapılarak } \\
\text { çalınmıștır. }\end{array}$ & $\begin{array}{l}\text { Şarkıda } \\
\text { bütünlük yoktur. }\end{array}$ \\
\hline
\end{tabular}

\begin{tabular}{|c|c|c|c|c|}
\hline Gözlenen & Cok iyi & Iyi & Orta & Zayif \\
\hline Davranıșlar & 4 & 3 & 2 & 1 \\
\hline $\begin{array}{l}\text { Notalar süre } \\
\text { degerlerine } \\
\text { uygun okuma }\end{array}$ & $\begin{array}{l}\text { Notalari süre } \\
\text { degerlerine } \\
\text { ritmik yapiya } \\
\text { uygun } \\
\text { okumugtur. }\end{array}$ & $\begin{array}{l}\text { Notalari süre } \\
\text { degerlerine } \\
\text { ritmik genel } \\
\text { anlamda uygun } \\
\text { okumugtur. }\end{array}$ & $\begin{array}{l}\text { Notalari süre } \\
\text { degerlerine } \\
\text { bazen hatalar } \\
\text { yapmiştur. }\end{array}$ & $\begin{array}{lr}\text { Notaları } & \text { süre } \\
\text { degerlerine } & \text { ritmik } \\
\text { yapiya } & \text { uygun } \\
\text { okumamıstır. }\end{array}$ \\
\hline $\begin{array}{l}\text { Notalari } \\
\text { müzilcsel } \\
\text { seslerine uygun } \\
\text { okuma }\end{array}$ & $\begin{array}{l}\text { Notalari } \\
\text { muziksel } \\
\text { seslerine uygun } \\
\text { okumuştur. }\end{array}$ & $\begin{array}{l}\text { Notaları } \\
\text { muziksel } \\
\text { seslerine genel } \\
\text { olarak uygun } \\
\text { okumuştur. }\end{array}$ & $\begin{array}{l}\text { Notaları } \\
\text { muziksel } \\
\text { seslerine uygun } \\
\text { okumada bazen } \\
\text { hatalar } \\
\text { yapmıştır. }\end{array}$ & 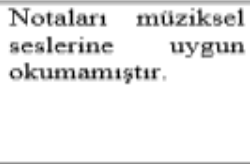 \\
\hline Bätünlak & $\begin{array}{l}\text { Sarkinin } \\
\text { tamaminda } \\
\text { butun olarak } \\
\text { duraksamadan } \\
\text { muziksel okuma } \\
\text { yapilmıştır. }\end{array}$ & $\begin{array}{l}\text { Sarkinin } \\
\text { tamamında } \\
\text { genel olarak } \\
\text { duraksamadan } \\
\text { muziksel okuma } \\
\text { yapilmıştır. }\end{array}$ & $\begin{array}{l}\text { Sarkıda bazen } \\
\text { duraksamalar } \\
\text { yapılarak } \\
\text { müziksel okuma } \\
\text { yapilmıştır. }\end{array}$ & $\begin{array}{l}\text { Sarkida } \\
\text { yoktur. }\end{array}$ \\
\hline
\end{tabular}

\section{Verilerin Analizi}

37 maddelik başarı testi öğretmen adaylarına uygulandıktan sonra teste en çok doğru cevap veren öğretmen adaylarının puanları sıralanmıştır. \%27'lik alt ve üst gruplar belirlenmiştir. Buna göre çalışma grubunu (50x27/100=13,5) üst grup 14 öğretmen adayı ve alt grup 14 öğretmen adayı olmak üzere toplam 28 öğretmen adayı oluşturmuştur. Öğretmen adaylarının müziksel bilgilerini ölçmek için başarı testinde yer alan çoktan seçmeli sorulara verdikleri cevaplar betimsel istatistik kullanılarak analiz edilmiştir. Araştırma grubunu oluşturan öğretmen adaylarının 37 sorudan oluşan başarı testinden aldıkları 
puanlar bilgisayar ortamına aktarılmış ve SPSS 17 programı kullanılarak analiz edilmiştir. Öğretmen adaylarına başarı testi uygulandıktan sonra cevap kağıtları inceleme sırasında kodlanmıştır. Ö1-Ö50 arasında numaralar verilmiştir.

\section{Bulgular}

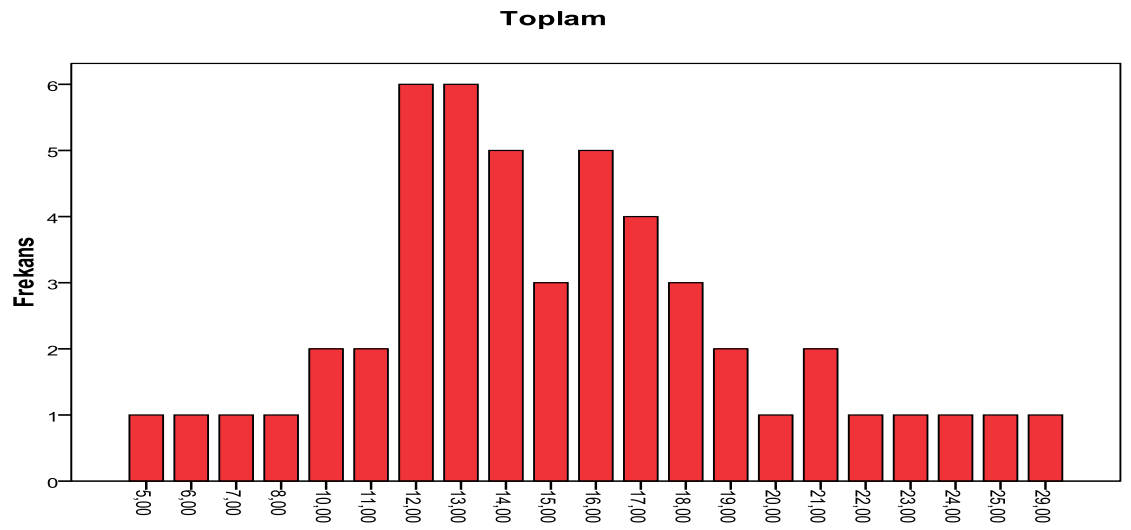

Grafik 1'e göre sınıf öğretmeni adayları 37 maddelik başarı testinde en yüksek 29 ve en düşük 5 soruya doğru cevap vermişlerdir. Buradan yola çıarak öğretmen adaylarının başarı testinden aldıkları puanların dağınık bir dağılım gösterdiği söylenebilir.

Grafik 1 incelendiğinde öğretmen adaylarından toplam 40'ı maksimum 18 ve daha az sayıda soruya doğru cevap vermişlerdir. Diğer bir ifadeyle katılımciların \%80'i 37 sorudan oluşan başarı testini \%50 ve altındaki oranlarda doğru cevaplamışlardır. 9 öğretmen adayının doğru cevapladığı soru sayıları 19 ile 25 arasında değişmektedir. 1 öğretmen adayı ise 29 soruya doğru cevap vererek katılımcilar arasında en fazla doğru sayısına sahip olduğu görülmektedir. Bu bulgulara dayanarak öğretmen adaylarının temel müzik bilgilerinin yetersiz olduğu söylenebilir. Öğretmen adayları başarı testine en çok doğru cevap verenden en az doğru cevap verene doğru sıralanmıştır. 
Tablo 4. Öğretmen Adaylarııın Başarı Testine Verdikleri Cevapların Toplam Doğru Sayıları

\begin{tabular}{ll}
\hline Ögrretmen Aday1 Kod & Doğru Say1s1 \\
\hline Ö1 & 5 \\
\hline Ö2 & 6 \\
\hline Ö3 & 7 \\
\hline Ö4 & 8 \\
\hline Ö5, Ö6 & 10 \\
\hline Ö7, Ö8 & 11 \\
\hline Ö9, Ö10, Ö11, Ö12, Ö13, Ö14 & 12 \\
\hline Ö15, Ö16, Ö17, Ö18, Ö19, Ö20 & 13 \\
\hline Ö21, Ö22, Ö23, Ö24, Ö25 & 14 \\
\hline Ö26, Ö27, Ö28 & 15 \\
\hline Ö29, Ö30, Ö31, Ö32, Ö33 & 16 \\
\hline Ö34, Ö35, Ö36, Ö37 & 17 \\
\hline Ö38, Ö39, Ö40 & 18 \\
\hline Ö41, Ö42 & 19 \\
\hline Ö43 & 20 \\
\hline$\ddot{O} 44$, Ö45 & 21 \\
\hline$\ddot{O} 46$ & 22 \\
\hline$\ddot{O} 47$ & 23 \\
\hline Ö48 & 24 \\
\hline Ö49 & 25 \\
\hline$\ddot{O} 50$ & 29 \\
\hline
\end{tabular}

Çalışmanın uygulama bölümünde, incelenecek öğretmen adaylarının müzik eğitimi derslerinde notayla şarkı öğretim yöntemine göre öğretimi yapılan okul şarkıları dağarcığındaki örneklerde blokflüt çalma ve müziksel okuma (solfej) becerilerini ölçmek amaciyla \%27'lik üst ve alt gruplar tespit edilmiştir. Buna göre çalışmanın üst grubunu başarı testine en çok doğru cevap veren 14 öğretmen adayı (Ö37-Ö50) ile alt grubunu en az doğru cevap veren 14 öğretmen adayı (Ö23-Ö36) olmak üzere toplam 28 öğretmen adayı belirlenmiştir. Uygulamada aşağıdaki şarkılar kullanılmıştır. Bireysel çalma ve müziksel okuma becerilerinin değerlendirilmesi aşamasında her bir öğretmen adayı gözlenerek dereceli puanlama anahtarı aracılığı ile alan uzmanı 2 müzik eğitimcisi tarafından puanlanmıştır. Daha sonra iki alan uzmanı bir araya gelerek her bir öğretmen adayı için verdikleri puanları karşılaştırmışlardır. Karşılaştırmalarda görüş birliği ve görüş ayrılığı tespit edilerek dereceli puanlama anahtarlarının güvenilirliği Miles ve Huberman'ın (1994) Güvenirlik= Görüş birliği / Görüş ayrıllı̆g formülü kullanılarak hesaplanmıştır. 
Miles ve Huberman (1994) araştırmacı değerlendirmeleri arasındaki değerlendirmeleri arasındaki uyumun \%90 ve üzerinde bir değer olması gerektiğini belirtmiştir. Bu araştırmaya özgü olarak gerçekleştirilen güvenirlik çalışmasında uzmanlar arasında \%93 oranında bir güvenirlik (uzlaşma) sağlanmıştır.

- Biricik Öğretmenim (Söz ve Müzik: Selçuk Yıldırım, Besim Akkuş)

- Ağaca Övgü (Söz ve Müzik: Sefai Acay)

- Halay (Söz ve Müzik: Saip Egüz)

- Çocuk ve Çiçek (Söz ve Müzik: Mahir Dinçer)

- Mevsimler (Söz ve Müzik: Sefai Acay)

- Gel Bize Katıl Bize (Söz ve Müzik: Muammer Sun)

- Yüksek Dağlar (Söz ve Müzik: Sefai Acay)

- Hayvanlar (Söz ve Müzik: Saip Egüz)

- Samsun'dan Doğan Güneş (Söz ve Müzik: Sefai Acay)

- Çocuk ve Çiçek (Söz ve Müzik: Mahir Dinçer)

Öğretmen adaylarının okul şarkıları dağarcığındaki örneklerde blokflüt çalma düzeyleri Tablo 5'te gösterilmiştir.

Tablo 5'e bakıldığında üst grupta yer alan Ö49, Ö50 kodlu öğretmen adaylarının blokflüt çalma düzeylerinin çok iyi olduğu, Ö46, Ö47, Ö48 kodlu öğretmen adaylarının iyi düzeyde çaldıkları, Ö45 kodlu öğretmen adayının doğru tutuş ve üfleme ile temiz seslerle çalmada iyi, notaları süre değerlerine uygun çalma, hız ve bütünlük ölçütlerine göre orta düzeyde çaldığı görülmektedir.

Alt grubu oluşturan öğretmen adaylarından 2' si (Ö35, Ö36) blokflüt çalma becerilerinin iyi düzeyde olduğu, 3’ü (Ö32, Ö33,Ö34) orta düzeyde, Ö30 ve Ö31 kodlu öğretmen adaylarının blokflüt tutuş ve üfleme ile temiz seslerle çalmada orta düzeyde, süre değerlerine uygun çalma, hız ve bütünlük ölçütlerine göre zayıf düzeyde oldukları, 7'sinin (Ö23,Ö24,Ö25,Ö26,Ö27,Ö28,Ö29) blokflüt çalma beceri düzeylerinin dereceli puanlara anahtarından aldıkları puanlara göre zayıf düzeyde olduğu belirlenmiştir. 
Tablo 5. Blokflüt çalma becerilerinin değerlendirilmesinde kullanılan dereceli puanlama anahtarn

\begin{tabular}{|c|c|c|c|c|c|c|c|c|}
\hline \multirow[b]{2}{*}{ Gözlenen Davranışlar } & \multicolumn{4}{|c|}{ ÜST GRUP } & \multicolumn{4}{|c|}{ ALT GRUP } \\
\hline & Çok iyi & İyi & Orta & Zayif & Çok iyi & İyi & Orta & Zayıf \\
\hline & 4 & 3 & 2 & 1 & 4 & 3 & 2 & 1 \\
\hline \multirow[t]{7}{*}{ Doğru ve temiz seslerle çalma } & Ö49 & Ö45 & Ö43 & Ö37 & & Ö35 & Ö30 & Ö23 \\
\hline & Ö50 & Ö46 & Ö44 & Ö38 & & Ö36 & Ö31 & Ö24 \\
\hline & & Ö47 & & Ö39 & & & Ö32 & Ö25 \\
\hline & & Ö48 & & Ö40 & & & Ö33 & Ö26 \\
\hline & & & & Ö41 & & & Ö34 & Ö27 \\
\hline & & & & Ö42 & & & & Ö28 \\
\hline & & & & & & & & Ö29 \\
\hline \multirow[t]{9}{*}{ Doğru tartımda çalma } & Ö49 & Ö46 & Ö43 & Ö37 & & Ö35 & Ö32 & Ö23 \\
\hline & Ö50 & Ö47 & Ö44 & Ö38 & & Ö36 & Ö33 & Ö24 \\
\hline & & Ö48 & Ö45 & Ö39 & & & Ö34 & Ö25 \\
\hline & & & & Ö40 & & & & Ö26 \\
\hline & & & & Ö41 & & & & Ö27 \\
\hline & & & & Ö42 & & & & Ö28 \\
\hline & & & & & & & & Ö29 \\
\hline & & & & & & & & Ö30 \\
\hline & & & & & & & & Ö31 \\
\hline \multirow[t]{9}{*}{ Bütünlük } & Ö49 & Ö46 & Ö43 & Ö37 & & Ö35 & Ö32 & Ö23 \\
\hline & Ö50 & Ö47 & Ö44 & Ö38 & & Ö36 & Ö33 & Ö24 \\
\hline & & Ö48 & Ö45 & Ö39 & & & Ö34 & Ö25 \\
\hline & & & & Ö40 & & & & Ö26 \\
\hline & & & & Ö41 & & & & Ö27 \\
\hline & & & & Ö42 & & & & Ö28 \\
\hline & & & & & & & & Ö29 \\
\hline & & & & & & & & Ö30 \\
\hline & & & & & & & & Ö31 \\
\hline
\end{tabular}

Öğretmen adaylarının okul şarkıları dağarcığındaki örneklerde müziksel okuma (solfej) düzeyleri Tablo 6'da gösterilmiştir.

Müziksel okuma esnasında öğretmen adaylarına seslendirecekleri şarkının ilk motifi çalınarak sesi doğru almaları sağlanmış şarkının geri kalanı piyano ile çalınmadan okumaları istenmiştir. 
Tablo 6. Öğretmen adaylarının müziksel okuma (solfej) düzeylerinin değerlendirilmesinde kullanılan dereceli puanlama anahtarı

\begin{tabular}{|c|c|c|c|c|c|c|c|c|}
\hline \multirow[b]{2}{*}{ Gözlenen Davranışlar } & \multicolumn{4}{|c|}{ ÜST GRUP } & \multicolumn{4}{|c|}{ ALT GRUP } \\
\hline & $\begin{array}{c}\text { Çok iyi } \\
4 \\
\end{array}$ & $\begin{array}{l}\text { İyi } \\
3 \\
\end{array}$ & $\begin{array}{c}\text { Orta } \\
2 \\
\end{array}$ & $\begin{array}{c}\text { Zaylf } \\
1 \\
\end{array}$ & $\begin{array}{c}\text { Çok iyi } \\
4 \\
\end{array}$ & $\begin{array}{c}\text { İyi } \\
3 \\
\end{array}$ & $\begin{array}{c}\text { Orta } \\
2 \\
\end{array}$ & $\begin{array}{c}\text { Zayif } \\
1\end{array}$ \\
\hline $\begin{array}{l}\text { Notaları süre } \\
\text { değerlerine ritmik yapıya } \\
\text { uygun okuma }\end{array}$ & $\begin{array}{l}\text { Ö48 } \\
\text { Ö49 } \\
\text { Ö50 }\end{array}$ & $\begin{array}{l}\text { Ö45 } \\
\text { Ö46 } \\
\text { Ö47 }\end{array}$ & $\begin{array}{l}\text { Ö40 } \\
\text { Ö41 } \\
\text { Ö42 } \\
\text { Ö43 } \\
\text { Ö44 }\end{array}$ & $\begin{array}{l}\text { Ö37 } \\
\text { Ö38 } \\
\text { Ö39 }\end{array}$ & & $\begin{array}{l}\text { Ö33 } \\
\text { Ö34 } \\
\text { Ö35 } \\
\text { Ö36 }\end{array}$ & $\begin{array}{l}\text { Ö30 } \\
\text { Ö31 } \\
\text { Ö32 }\end{array}$ & $\begin{array}{l}\text { Ö23 } \\
\text { Ö24 } \\
\text { Ö25 } \\
\text { Ö26 } \\
\text { Ö27 } \\
\text { Ö28 } \\
\text { Ö29 }\end{array}$ \\
\hline $\begin{array}{l}\text { Notaları müziksel seslerine } \\
\text { uygun okuma }\end{array}$ & $\begin{array}{l}\text { Ö48 } \\
\text { Ö49 } \\
\text { Ö50 }\end{array}$ & $\begin{array}{l}\text { Ö46 } \\
\text { Ö47 }\end{array}$ & $\begin{array}{l}\text { Ö43 } \\
\text { Ö44 } \\
\text { Ö45 }\end{array}$ & $\begin{array}{l}\text { Ö37 } \\
\text { Ö38 } \\
\text { Ö39 } \\
\text { Ö40 } \\
\text { Ö41 } \\
\text { Ö42 }\end{array}$ & & Ö36 & $\begin{array}{l}\text { Ö31 } \\
\text { Ö32 } \\
\text { Ö33 } \\
\text { Ö34 }\end{array}$ & $\begin{array}{l}\text { Ö23 } \\
\text { Ö24 } \\
\text { Ö25 } \\
\text { Ö26 } \\
\text { Ö27 } \\
\text { Ö28 } \\
\text { Ö29 } \\
\text { Ö30 }\end{array}$ \\
\hline Bütünlük & $\begin{array}{l}\text { Ö48 } \\
\text { Ö49 } \\
\text { Ö50 }\end{array}$ & $\begin{array}{l}\text { Ö46 } \\
\text { Ö47 }\end{array}$ & $\begin{array}{l}\text { Ö43 } \\
\text { Ö44 } \\
\text { Ö45 }\end{array}$ & $\begin{array}{l}\text { Ö37 } \\
\text { Ö38 } \\
\text { Ö39 } \\
\text { Ö40 } \\
\text { Ö41 } \\
\text { Ö42 }\end{array}$ & & $\begin{array}{l}\text { Ö35 } \\
\text { Ö36 }\end{array}$ & $\begin{array}{l}\text { Ö31 } \\
\text { Ö32 } \\
\text { Ö33 } \\
\text { Ö34 }\end{array}$ & $\begin{array}{l}\text { Ö23 } \\
\text { Ö24 } \\
\text { Ö25 } \\
\text { Ö26 } \\
\text { Ö27 } \\
\text { Ö28 } \\
\text { Ö29 } \\
\text { Ö30 }\end{array}$ \\
\hline
\end{tabular}

Tablo 6'ya bakıldığında üst grupta yer alan Ö48, Ö49, Ö50 kodlu öğretmen adaylarının müziksel okuma düzeylerinin çok iyi olduğu, Ö46, Ö47 kodlu öğretmen adaylarının müziksel okuma düzeylerinin iyi, Ö45 kodlu öğretmen adayının notaları süre değerlerine uygun okuma düzeyinin iyi, notaları müziksel seslerine uygun okuma ve bütünlük ölçütlerine göre orta düzeyde olduğu görülmektedir. Öğretmen adaylarından 2'sinin (Ö43 ve Ö44) müziksel okuma düzeylerinin orta, Ö40, Ö41 ve Ö42 kodlu öğretmen adaylarının notaları ritimsel okuma düzeylerinin orta, müziksel okuma düzeylerinin zayıf olduğu görülmektedir.

Alt grupta yer alan öğretmen adaylarının müziksel okuma düzeylerinin sonuçlarına bakıldığında 2' sinin (Ö35, Ö36) müziksel okuma düzeylerinin iyi olduğu, Ö33, Ö34 kodlu öğretmen adaylarının notaları süre değerlerine uy- 
gun okuma düzeyinin iyi, notaları müziksel seslerine uygun okuma ve bütünlük ölçütlerine göre orta düzeyde olduğu görülmektedir. Ö31, Ö32 kodlu öğretmen adaylarının orta düzeyde müziksel okuma becerisine sahip oldukları, Ö30 kodlu öğretmen adayının notaları ritimsel okumada orta, müziksel okuma ve bütünlük ölçütlerine göre zayıf düzeyde olduğu görülmektedir. Öğretmen adaylarının 7'si (Ö23, Ö24, Ö25, Ö26, Ö27, Ö28, Ö29) okul şarkılarında müziksel okuma düzeylerinin zayıf olduğu belirlenmiştir.

\section{Sonuç ve Tartışma}

Araştırma sonucunda öğretmen adaylarının okul şarkılarında geçen temel müzik bilgilerini ölçen başarı testinde yer alan sorulara verdikleri cevapların dağınık bir dağılım gösterdiği, belirlenmiştir. Öğretmen adaylarının \% 80'i $(n=40)$ toplam 37 soruluk başarı testinde 18 ve daha az sayıdaki soruya doğru cevap vermişlerdir. Öğretmen adaylarının \%20'si ise (10 öğretmen adayı) toplam 19-29 aralığında doğru cevap vermişlerdir. Bu bulguya dayanarak öğretmen adaylarının temel müzik bilgilerinde önemli ölçüde eksiklikler olduğu söylenebilir.

Araştırma grubunda yer alan öğretmen adaylarının çalışma kapsamında belirlenen okul şarkılarında blokflüt çalma becerilerinde üst grupta 3 öğretmen adayının "orta", 6 öğretmen adayı ise "zayıf" düzeyde; alt grupta ise 5 öğretmen adayının "orta", 9 öğretmen adayı ise "zayıf" düzeydedir. Müziksel okuma düzeylerinin üst grupta 6 öğretmen adayı "orta" ve 3 öğretmen adayının "zayıf" düzeyde, alt grupta ise 5 öğretmen adayının "orta" ve 8 öğretmen adayının "zayıf" düzeyde olduğu saptanmıştır.

Elde edilen tüm sonuçlar karşılaştırıldığında sınıf öğretmeni adaylarının bilişsel alanda temel müzik bilgileri ile uygulamadaki blokflüt çalma ve müziksel okuma düzeylerinin yetersiz olduğu belirlenmiştir.

Afacan (2010); çalışmasında sınıf öğretmeni adaylarının çalma, müziksel okuma ve deşifre düzeylerinin bilgi düzeylerine göre düşük olduğunu belirtmiştir. Koca ve Kurtaslan (2013), çalışmalarında sınıf öğretmeni adaylarının şarkıların nota değerlerini doğru ve ritmik okuyabilme boyutlarında sorunlar yaşadıklarını belirtmişlerdir. Arapgirlioğlu ve Karagöz, (2010), Yünlü ve Sağlam (2004), çalışmalarında tartım eğitimi, solfej ve bona çalışmalarında ciddi güçlükler yaşandığını belirtmişlerdir. Bu çalışmaların sonuçları yapılan araştırmanın sonuçları ile benzerlik göstermektedir. 
Yazıcı (2016), Yünlü ve Sağlam (2004) ve Yazıcı (2012), çalışmalarında da sını öğretmenlerinin müzik derslerindeki kazanımlara yeterli zaman ayıramadıkları, bu dersin işlenişinde zorluklar yaşadıkları, müzik dersinin işlenmesi için yeterli donanıma ve ortama sahip olmadıkları ve bu dersin müzik öğretmenlerince verilmesi gerekliğini belirtmişlerdir.

Umuzdaş ve Işıldak (2019), Barış ve Özata (2009), Göğüş (2008), Kalyoncu ve Öztürk (2009), Kocabaş (2000), Şahin ve Aksüt (2002), Şaktanlı (2004), Kutluk (2010), Öztürk ve Öztürk (2007) ve Çelik (2001), çalışmalarında sınıf öğretmenlerinin müziksel donanımlarında eksikliklerinin olduğu, sınıf öğretmeni adaylarının ise müzik öğretimi uygulamalarında kendilerinin yetersiz gördüklerini vurgulamışlardır. Benzer şekilde Kocamanoğlu (2019) sınıf öğretmenlerinin müzik eğitimi yeterlik düzeylerini ölçmek amacıyla gerçekleştirdiği çalışmasında kuramsal bilgi seviyelerinin orta ve düşük seviyede, solfej okuma becerilerinin ise orta düzeyde olduğunu belirlemiştir. Belirtilen çalışmaların sonuçları yapılan araştırma sonuçları ile örtüşmekte olup, çalışmayı destekler niteliktedir.

\section{Öneriler}

Günümüzde lisans sürecinde sınıf öğretmenliği anabilim dallarında müzik ders saatleri daha da azaltılmıştır. Bu durum sınıf öğretmeni olacak adayların ilgi, yetenek ve kişisel özelliklerinin farklılı̆̆ı da göz önüne alındığında gereken donanıma sahip olmalarını daha da güçleştirecektir. Bu nedenle müzik ders içeriklerinin geliştirilerek ders saatlerinin arttırılması gerekir.

Müzik derslerinde bona ve solfej eğitimine daha fazla yer verilebilir. Çalg1 eğitimi ve eşlikli söyleme ve çalma uygulamalarına ağırlık verilebilir. Seçmeli çalg1 (bağlama, gitar, mandolin vb.) dersleri açlabilir. Müzik derslerinde çalışılan okul şarkılarından oluşan repertuvar birlikte çalma ve söyleme etkinlikleri düzenlenerek ders dışı zamanlarda sergilenebilir. Öğretmen adaylarında müzik yapma ve dinleme isteği geliştirilebilir. 


\title{
EXTENDED ABSTRACT
}

\section{Comparison of Musical Knowledge of Pre-Service Teachers with Block flute Playing and Musical Reading Levels}

\author{
Aylin Mentiş Köksoy - Şenol Afacan \\ Ege University - Kırşehir Ahi Evran University
}

Class teachers are people who have an important role in developing the mental and working habits of children, from primary school to the fifth grade, and playing an important role in shaping their education life. They are also the ones that enable children to acquire the knowledge, skills and qualifications they need to express themselves and to develop in primary school and beyond. During the 4-year undergraduate education, classroom teachers are at the forefront of the lessons that provide the socialization of children, such as music, as well as various courses that can be the basis for students, and which are known to support the mental development of children.

The elementary teacher candidates are also expected to acquire competencies and skills developed in the field. One of the special field competencies that classroom teachers, which was determined by the Ministry of National Education, General Directorate of Teacher Training and Education and entered into force in 2008, is "art and aesthetics". This competence area; It includes the basic knowledge of fine arts (music, painting) and the use of artistic activities in the process of learning (MEB, 2008, p.10). Primary education includes basic dimensions such as music education, musical hearing, musical singing, playing instruments, listening to music, increasing musical sensitivity, developing musical taste and developing musical personality (Kocabaş, 1995, p.5).

Music teaching in primary schools is carried out within the scope of educational music teaching. Considering that every elementary school child receives this education, which is an effective educational basis-size-tool-method-area, the music teaching carried out in these institutions should be handled without being ignored with its complementary, supportive, creativity and forward-looking functions (Sun, 1969; Yıldız, 2006). Transfer by Yazıc1, 2016). 
If the teacher has a correct and consistent musical ability or understanding of musicality, the teacher can train to understand, make, create and use music correctly; can shape and develop student's musical abilities accurately and consistently (Uçan, 2005).

A qualified classroom teacher; In addition to general culture courses, it should be equipped in private courses. For example, they should know the basic music texts and elements in the elementary music lesson curriculum, be able to sing the songs correctly, be able to accompany the songs with a school instrument or orff instrument, present samples from the music of different cultures to students, and enable students to reveal their musical creativity aspects. "The sound network that encompasses itself in the education process of the elementary school child and the music and musical environment within the sound environment that this network is built has different characteristics than natural, social and cultural sounds" (Uçan, 1999, p.2).

It is important for the elementary teacher candidates to acquire musical knowledge and skills, to acquire the skills to apply the theoretical knowledge they have learned and to be trained on these subjects in a qualified manner (Çevik, 2011, p.147). The elementary teacher candidates should be qualified to perform sound training, ear training, instrument training, musical knowledge training, musical taste training, which are the dimensions of music teaching (Afacan, 2007, p.89).

It is very important for elementary teacher candidates to be able to decipher in music lessons, to play and sing children's songs. They are asked to play the songs correctly and sing correctly because singing has been an ongoing music event. In addition to playing and singing, they are expected to master basic music knowledge levels. Prospective teachers' having the necessary musical equipment will make them more confident, effective and productive in their future lives. In addition to teaching music, playing blockblocks and musical reading in music lessons, students will be more motivated and will benefit their personal development positively. Music teaching is a versatile process that covers students' basic musical knowledge levels, playing and musical reading processes.

It is directly related to the fact that the prospective classroom teachers have the necessary equipment in music lessons. In this study, it is aimed to compare the basic knowledge of music teacher and music reading skill levels of class teacher candidates studying at Ege University Faculty of Education 
Class Education Department by identifying block flute playing and musical reading skill levels. In the study, 37-item achievement test developed by Afacan (2010) was used to measure the level of knowledge of prospective classroom teachers for musical information in songs in educational music repertoire. The KR-20 reliability coefficient of the developed achievement test was 0.81 . The study was carried out with 50 prospective classroom teachers who took music education course. A total of 28 prospective teachers with the highest and lowest scores in the achievement test were evaluated using the graded scoring key prepared by the researchers. As a result of the research, it was determined that prospective classroom teachers were inadequate according to the achievement test which measured basic music knowledge of school songs and it was found that block flute playing and musical reading levels were moderate and weak.

\section{Kaynakça / References}

Acay, S. (1990). Ezgi yumağı. Ankara: Ezgi Yayıncilık.

Afacan, Ş. (2007). Sımı öğretmeni adaylarının müzik öğretimine yönelik öz-yeterlilik düzeylerinin tespiti. XVI. Ulusal Eğitim Bilimleri Kongresi, Gaziosmanpaşa Üniversitesi Eğitim Fakültesi, 5-7 Eylül, Tokat

Afacan, Ş. (2010). Sını öğretmeni adaylarının çocuk şarkılarını bilişsel çözümleme ve uygulama düzeyleri. Ege Ĕ̆itim Dergisi, 11(2), 89-106.

Arapgirlioğlu, H. ve Karagöz, B. (2010). Sinıföğretmenliğinde müzik eğitimi sürecinin durumu ve değerlendirilmesi. 9. Sınıf Öğretmenliği Eğitimi Sempozyumu, 20-22 Mayıs, Elazığ.

Barış, D. A., Özata, E. (2009). Sınıf öğretmenliği anabilim dalında alınan müzikmüzik öğretimi derslerinin öğretmenlik uygulamalarındaki yansımaları. Mehmet Akif Ersoy Üniversitesi Ĕ̆itim Fakültesi Dergisi, 18, 27-42.

Creswell, J. W. (2017). Araştırma deseni: Nitel, nicel ve karma yaklaşımları (Çev. Ed. Selçuk Beşir Demir). Ankara: Eğiten Kitap.

Çevik, D.B. (2011). Sınıf öğretmeni adaylarının müzik öğretimi özyeterlik düzeylerinin incelenmesi. Ahi Evran Üniversitesi Eğitim Fakültesi Dergisi, 12(1), 145-168.

Çelik, B., (2001). Sını öğretmeni adaylarının müzik eğitimi ve öğretimi konusundaki donanımları üzerine bir araştırma. (Yayımlanmamış yüksek lisans tezi) Gazi Üniversite Eğitim Bilimleri Enstitüsü, Ankara. 
Demirbatır, E. ve Helvacı, A. (2006). Uludağ üniversitesï eğitim fakültesi sınıf öğretmenliği anabilim dalı öğrencilerinin müzik derslerine ilişkin görüş ve beklentilerinin değerlendirilmesi. Ulusal Müzik Ĕ̆itimi Sempozyumu Bildirisi, 26-28 Nisan 2006, Pamukkale Üniversitesi Eğitim Fakültesi, Denizli.

Dinç Altun, Z. ve Uzuner, F. G. (2018). Sınıf öğretmenlerinin müzik öğretimine yönelik görüşlerinin incelenmesi. Abant İzzet Baysal Üniversitesi Eğitim Fakültesi Dergisi, 18 (3), 1416-1432.

Egüz, S. (1981). Çocuklarımıza yeni şarkılar. Ankara: Ayyıldız Matbaası.

Göğüş, G. (2008). Müziksel ve matematiksel öğrenme başarısı arasındaki ilişki. Uludağ Üniversitesi Ĕ̆itim Fakültesi Dergisi, 21(1), 79-89.

Kalyoncu N. ve Öztürk, Ö. (2009). Sinıf öğretmenliği anabilim dallarında verilen müzik ve müzik öğretimi derslerinin içerikleri. 8. Ulusal Müzik Eğitimi Sempozyumu, 23-25 Eylül 2009.

Kocabaş, A. (1995). İşbirlikli öğrenmenin blokflüt öğretimi ve öğrenme stratejileri üzerindeki etkileri. (Yayımlanmamış doktora tezi). Dokuz Eylül Üniversitesi Fen Bilimleri Enstitüsü, İzmir.

Kocabaş, A. (2000). İlköğretim okulları beşinci sınıf müzik derslerinde uygulanan işbirlikli öğretmenin müzikte benlik kavramı üzerine etkileri. Pamukkale Üniversitesi Ĕ̆itim Fakültesi Dergisi, 7(7), 13-17.

Kocabaş, A. ve Selçioğlu, E. (2006). İlköğretim okulları 4. ve 5. sınıflarında müzik dersinin gerçeleşme düzeyi ve öğrencilerin beklentilerine ilişkin görüşleri. Pamukkale Üniversitesi Eğitim Fakültesi Dergisi, 19, 56-66.

Kocamanoğlu, K. (2019). Sınıföğretmenlerinin müzik eğitimi yeterliği. Yayınlanmamış Yüksek Lisans Tezi, Pamukkale Üniversitesi Eğitim Bilimleri Enstitüsü, Denizli.

Kutluk, Ö. (2010). Sınıf öğretmeni adaylarının müzik eğitimleri ve üniversitede aldıkları müzik eğitimine ilişkin görüşleri. Selçuk Üniversitesi Ahmet Keleşoğlu Eğitim Fakültesi Dergisi, 29, 275-288.

Kurtaslan, H. ve Koca, Ş. (2013). Sınıf öğretmeni adaylarının müzik dersleri kapsamında aldıkları blokflüt eğitimine yönelik bakış açıları. Ĕ̆itim ve Öğretim Araştırmaları Dergisi (JRET), 2(4), 145-151.

Küçüküncü, Y. (2000). Sinıf öğretmenliğinde müzik eğitimi. Pamukkale Üniversitesi Ĕ̆itim Fakültesi Dergisi, 7(7), 8-12.

Kılıç, I. (2011). Sınıf Öğretmeni adaylarının müzik eğitimine yönelik görüşleri. E-journal of New World Sciences Academy, 6(4), Article Number: D0070 
MEB. (2007b). İlköğretim müzik 2 öğretmen kılavuz kitabı. İstanbul:Tavaslı Matbaacilık.

M.E.B. (2008). Sını öğretmeni özel alan yeterlikleri, Ankara: Talim Terbiye Kurulu Başkanlığı.

Miles, M. B. ve Huberman, A. M. (1994). Qualitative data analysis (2nd edition). Thousand Oaks, California: SAGE Publications.

Milli, S. M. (1999). İlköğretim okullarında piano ve klavyeli çalgıların müzik öğretmenleri tarafından kullanımı ve eğitime katkıları. Yüksek Lisans Tezi, Pamukkale Üniversitesi, Sosyal Bilimler Enstitüsü, Denizli.

Nacakcı, Z. (2006, Nisan). ilköğretim öğrencilerinin müzik dersine ilişkin tutumları. Ulusal Müzik Eğitimi Sempozyumu, Denizli.

Nart, S. (2014). Sınıföğretmenliği eğitiminde müzik dersleri. Trakya Üniversitesi, 9. Balkan Eğitim ve Bilim Kongresi, Edirne.

Otacıoğlu, S. (2007). İlköğretim 5., 6. ve 7. sınıf öğrencilerinin müzik dersine ilişkin tutumlarının incelenmesi. Dokuz Eylül Üniversitesi Buca Eğitim Fakültesi Dergisi, 21, 134-139.

Özdemir, G. ve Yıldız, G. (2010). Genel gelişim sürecinde müziksel gelişim. Mehmet Akif Ersoy Üniversitesi Sosyal Bilimler Enstitüsü Dergisi, 2(2), 7790.

Öztürk, G. ve Öztürk, Ö. (2007). İlköğretim I. kademe müzik dersinin etkin yürütülmesinde sınfföğretmeninin rolü (Bolu İli Örneği). 16. Ulusal Eğitim Bilimleri Kongresi, Tokat, Gaziosmanpaşa Üniversitesi.

Sun, M. (2000). Kır çiçekleri. Ankara: Yurtrenkleri Yayınevi.

Şahin, K. ve Aksüt, M. (2002). I. kademede müzik derslerine ilişkin öğretmen görüşleri. Afyon Kocatepe Üniversitesi Sosyal Bilimler Dergisi, 4(2), 105118.

Şaktanlı, C. (2004). Son sınıf öğrencilerinin lisans programlarında verilen müzik eğitimi derslerine ilişkin görüşleri. 1924-2004 Musiki Muallim Mektebinden Günümüze Müzik Öğretmeni Yetiştirme Sempozyumu. Isparta, Süleyman Demirel Üniversitesi, 271-283.

Şendurur, Y. ve Barış, D. A. (2002). Müzik eğitimi ve çocuklarda bilişsel başarı. G. Ü. Ĕ̆itim Fakültesi Dergisi, 22 (1), 165-174.

Topoğlu, O. (2015). Sınıf öğretmeni adaylarının müzik eğitimine ilişkin görüşleri. International Journal of Human Sciences, 12(2), 654-673.

Uçan, A. (1999). Illköğretimde müzik eğitimi. Burdur: Millî Eğitim Bakanlı̆̆ı.

Uçan, A. (2005). Müzik eğitimi temel kavramlar-ilkeler-yaklaşımlar ve Türkiye'deki durum (3. Basım). Ankara: Müzik Ansiklopedisi Yayınları. 
Umuzdaş, M. S. (2017). Müzik öğretmenliği öğrencilerinin elektronik org eğitimi dersindeki deşifre becerileri. International Journal Of Eurasia Social Sciences, 8 (28), CCXLIV-CCLIII.

Ustaoğlu B. ve Barış Dolunay A. (2017). Özel okullardaki öğrencilerin, öğretmenlerin ve yöneticilerin müzik dersine ilişkin görüşleri. Journal of Human Sciences, 14(4), 4701-4710.

Umuzdaş, S. ve Işıldak, K. C. (2019). İlköğretim müzik dersine ilişkin mevcut durumun sınıf öğretmeni adaylarının görüşlerine göre değerlendirilmesi. Kalem Eğitim ve insan Bilimleri Dergisi, 9(1), 117-133.

Yünlü, F. ve Sağlam, M. (2004). Sınıföğretmenlerinin müzik dersine ilişkin görüşleri, içerikle ilgili güçlükleri ve eğitim gereksinimleri. Eğitim Bilimleri ve Uygulama, 3(6), 211-226.

Yazıc1, T. (2012). İlköğretim müzik dersinin uygulanmasında karşılaşılan sorunların öğretmen görüşleri açısından değerlendirilmesi Trabzon ili örneği. Çukurova Üniversitesi Sosyal Bilimler Enstitüsü Dergisi, 21(1), 185-200.

Yazıcı, T. (2016). İlkokul 4. sınıf öğrencilerin müzik dersi öğretimi kazanım boyutları ile ilgili sını öğretmenleri görüşler. The Journal of Academic Social Science Studies, 46, 233-246.

Yıldırım, S. ve Akkuş, B. (1987). Halk ezgileriyle blokflüt metodu okul türkü dağarcı̆̆ 1 1. Ankara:Ezgi yayıncilık,.

Yılmaz, M.S. ve Orhan, Ş. (2018). Sınıf öğretmenliği bölümlerinin müzik dersi öğretim programı ve ders içeriklerinin incelenmesi. Online Journal of Music Sciences, 3 (2), 170-189.

Yüksek Öğretim Kurulu. Erişim adresi: http://www.yok.gov.tr/documents/10279/49665/sinif_ogretmenligi.pdf/32dd 5579-2e4d-454e8c91-5e0594ebdf48

\section{Kaynakça Bilgisi / Citation Information}

Mentiş-Köksoy, A. ve Afacan, Ş. (2020). Sınıf öğretmeni adaylarının müziksel bilgilerinin, blokflüt çalma ve müziksel okuma düzeyleri ile karşılaştırılması. OPUS-Uluslararası Toplum Araştırmaları Dergisi, 15(25), 3779-3799. DOI: 10.26466/opus. 653521 